\title{
Pengolahan Onggok Singkong sebagai Plastik Biodegradable Menggunakan Plasticizer Gliserin dari Minyak Jelantah
}

\section{Processing of Cassava Dregs (Onggok) as Biodegradable Plastic Using Glycerin Plasticizer from Waste Cooking Oil}

Dwi Fibriyani, Fera Arinta dan Ratna Dewi Kusumaningtyas*

Fakultas Teknik, Jurusan Teknik Kimia, Universitas Negeri Semarang, Semarang

*Korespondensi dengan penulis (ratnadewi.kusumaningtyas@mail.unnes.ac.id)

Artikel ini dikirim pada tanggal 12 Desember 2016 dan dinyatakan diterima tanggal 7 Mei 2017. Artikel ini juga dipublikasi secara online melalui www.jatp.ift.or.id. Hak cipta dilindungi undang-undang. Dilarang diperbanyak untuk tujuan komersial.

Diproduksi oleh Indonesian Food Technologists® @2017

\begin{abstract}
Abstrak
Pati dari onggok singkong berpotensi digunakan sebagai bahan utama pengolahan plastik. Kandungan amilosa yang tinggi dalam pati membuat film memiliki sifat yang rapuh. Untuk memperbaiki sifat-sifat film pati tersebut dilakukan dengan dipelukan plasticizer. Tujuan dari penelitian ini menentukan metode yang tepat untuk mengolah pati onggok singkong (POS) menjadi plastik biodegradable menggunakan gliserin dari minyak jelantah (GMJ), menentukan komposisi yang sesuai antara POS dengan platicizer; dan menentukan sifat biodegradabilitas dari plastik yang dihasilkan. Komposisi POS yang digunakan $15 \mathrm{~g}$ dan $30 \mathrm{~g}$ sedangkan GMJ adalah $5 \mathrm{ml}, 10 \mathrm{ml}$, dan $15 \mathrm{ml}$. Semakin besar POS dan semakin kecil GMJ menghasilkan derajat pengembunan yang semakin besar yaitu sekitar 37,5-47,27\%. Sampel dengan komposisi $15 \mathrm{~g}$ onggok singkong dan $15 \mathrm{ml}$ gliserin mengalami degradasi secara sempurna sehingga merupakan komposisi terbaik sebagai plastik biodegradable. Selain itu pada komposisi tersebut juga menghasilkan kuat tarik dan elastisitas yang baik dengan nilai pengembunan 40,42\%.
\end{abstract}

Kata kunci: pati onggok singkong, biodegradable, plasticizer, film plastik, gliserin

\section{Abstract}

Starch of cassava onggok potentially used as main material of plastic processing. Amylose content high in starch makes the film has a fragile nature. To improve the properties of starch film is done with plasticizer hugged. The purpose of this study was to determine the appropriate method for processing cassava starch (POS) into biodegradable plastic using glycerin from cooking oil (GMJ), determining the appropriate composition between $P O S$ and platicizer; and determine the biodegradability properties of the resulting plastic. The composition of POS used was $15 \mathrm{~g}$ and $30 \mathrm{~g}$ while the GMJ was $5 \mathrm{ml}, 10 \mathrm{ml}$, and $15 \mathrm{ml}$. The larger the POS and the smaller the GMJ produces a greater degree of condensation which is about 37.5-47.27\%. Samples with a composition of $15 \mathrm{~g}$ onggok cassava and $15 \mathrm{ml}$ of glycerin were degraded perfectly so it was the best composition as biodegradable plastic. In addition to the composition also produces a strong tensile strength and elasticity with a condensation value of $40.42 \%$.

Keywords: starch of cassava dreg (onggok), biodegradable, plasticizer, plastic film, glycerin

\section{Pendahuluan}

Limbah plastik sintetik menjadi salah satu permasalahan yang paling memprihatinkan di Indonesia. Jenis plastik yang beredar dimasyarakat merupakan plastik sintetik dari bahan baku minyak bumi yang terbatas jumlahnya dan tidak dapat diperbaharui. Plastik jenis ini tidak dapat terdegradasi oleh mikroorganisme atau sukar dirombak secara hayati (nonbiodegradable) di lingkungan karena mikroorganisme tidak mampu mengubah Jenis plastik yang beredar dan mensintesis enzim yang khusus untuk mendegradasi polimer berbahan dasar petrokimia (Darni dan Utami, 2010). Plastik sintetik baru dapat terdegradasi dalam waktu 450 hingga 600 tahun (Katz, 1995), sehingga dibutuhkan pengembangan dari plastik yang bersifat ramah lingkungan, bahan baku plastik tersedia dalam jumlah besar, berkelanjutan, dan mempunyai hasil yang berkekuatan sama dengan plastik sintetik.

Salah satu solusi bahan alam yang dapat menjadi bahan dasar pembuatan plastik biodegradable adalah onggok singkong yang merupakan limbah proses pembuatan tepung tapioka dari singkong. Onggok singkong juga berpotensi sebagai polutan karena dapat menimbulkan bau asam dan busuk (Mursyid et. al.,, 2009), mempunyai nilai ekonomi yang rendah, karbohidrat pada onggok singkong dapat diambil patinya, serta kurang banyak dimanfaatkan. Oleh karena itu, untuk meningkatkan nilai tambah dari onggok singkong maka dimanfaatkan sebagai bahan utama pengolahan plastik biodegradable.

Proses pengolahan plastik dari onggok singkong dilakukan dengan 5 tahapan yaitu pembuatan tepung, pencampuran bahan, pembentukan polimer, serta proses pencetakan plastik, dalam pengolahan plastik biodegradable diperlukan plasticizer. Plasticizer adalah senyawa yang memungkinkan plastik yang dihasilkan tidak kaku dan rapuh, dimana Penambahan pemlastis baik sintetis maupun alami bertujuan untuk memperbaiki sifat bioplastik yang dihasilkan, memperluas atau memodifikasi sifat dasarnya atau dapat memunculkan sifat baru yang tidak ada dalam bahan dasarnya (Spink and Waychoff, 1958). Pada pembuatan plastik sintetik sendiri biasanya dalam penambahan plasticizer masih menggunakan platicizer sintetis yang berasal dari golongan ftalat. Berdasarkan penelitian, ester turunan asam ftalat ini dapat membahayakan kesehatan, bahkan dapat 
menyebabkan kematian (Arban, 2007). Oleh karena itu, dalam penelitian ini selain bahan baku yang alami akan dikembangkan penggunaan plasticizer yang aman, yaitu gliserin yang meruapakan hasil samping reaksi transesterifikasi etanol dengan minyak jelantah. Jadi penggunaan gliserin dari minyak jelantah dapat digunakan sebagai plasticizer pengganti yang aman.

Penelitian tentang pembuatan plastik biodegradable dari pati yang berasal dari sumbersumber yang berbeda dengan plasticizer gliserin dari minyak jelantah telah dilakukan, dengan hasil dalam penelitiannya diperoleh ketahanan plastik biodegradable masih dipengaruhi variasi plasticizer dan bahan baku, dalam penelitian ini akan menggunakan 2 macam limbah yaitu: onggok singkong dan minyak jelantah. Dimana plastik biodegradable yang berasal dari onggok singkong dengan penambahan plasticizer gliserin dari minyak jelantah belum banyak dilakukan. Oleh karena itu, perlu dilakukan penelitian untuk membuat plastik biodegradable dari onggok singkong dengan penambahan plasticizer seperti gliserin untuk memperbaiki sifat mekanik plastik biodegradable. Dengan penelitian ini diharapkan memberikan konstribusi tepat guna dalam penggunaan plastik biodegradable. Bagi lingkungan hidup penelitian ini dapat mengatasi limbah plastik dan limbah minyak jelantah, bagi bangsa dan negara penelitian ini dapat memberikan solusi yang tepat untuk mengatasi penggunaan sampah sintesik, bagi pembangunan Nasional dapat mengefesiensi penggunaan lahan yang sekarang semakin minim.

\section{Materi dan Metode \\ Materi}

Bahan-bahan yang digunakan dalam penelitian ini adalah onggok singkong, aquades steril, larutan asam sitrat $5 \%$, spiritus, korek api, tanah, minyak jelantah, cuka, dan $\mathrm{NaOH}$. Peralatan yang digunakan selama penelitian adalah timbangan analitik, gelas kimia, gelas ukur 1 liter, gelas ukur $10 \mathrm{ml}$, kaki tiga, pipet, spatula, papan kayu, oven, blender atau mixer, saringan, termometer, cawan metrik, statif, magnetic stirer, pembakar bunsen, batang pengaduk, tabung reaksi, pipet ukur $1 \mathrm{ml}$, pipet ukur $10 \mathrm{ml}$, dan hot plat.

\section{Metode}

Penelitian berlangsung selama periode Juni Desember 2015. Penelitian meliputi proses pembuatan plastik biodegradable dari onggok singkong dan analisa karakteristik sifat plastik biodegradable. Analisi Karakteristik meliputi uji pengembunan, uji titik leleh, uji tarik, dan uji biodegradibilitas.

\section{Pembuatan Plastik Biodegradable}

Pertama-tama dibuat kontrol normal dengan mencampurkan 15 gram tepung maizena, $5 \mathrm{ml}$ borax gliserin, $5 \mathrm{ml}$ asam cuka dan $50 \mathrm{ml}$ akuades ke dalam gelas kimia. Campuran bahan-bahan tersebut dipanaskan dengan menggunakan bunsen kemudian diaduk dengan menggunakan batang pengaduk. Pemanasan dan pengadukan dilakukan hingga cairan mengental dan menyerupai lem. Setelah itu, campuran didinginkan sebentar dan dicetak dengan menggunakan spatula di papan kayu. Cetakan plastik biodegradable tersebut dikeringkan dengan menggunakan oven pada suhu $60^{\circ} \mathrm{C}$ selama 12 jam atau hanya dijemur dibawah terik matahari. Setelah kering, plastik dilepaskan dari cetakannya. Kemudian, sampel plastik biodegradable dibuat dengan bahan dasar tepung kulit pisang dan gliserin dari minyak jelantah. Proses pembuatan plastik biodegradable dapat dilakukan seperti langkah

di atas dengan komposisi :

1. 15 gram onggok singkong dan $5 \mathrm{ml}$ gliserin dari minyak jelantah

2. 15 gram onggok singkong dan $10 \mathrm{ml}$ gliserin dari minyak jelantah

3. 15 gram onggok singkong dan $15 \mathrm{ml}$ gliserin dari minyak jelantah

4. 30 gram onggok singkong dan $5 \mathrm{ml}$ gliserin dari minyak jelantah

5. 30 gram onggok singkong dan $15 \mathrm{ml}$ gliserin dari minyak jelantah

Uji Karakteristik

Uji Tarik

Komposisi optimal plastik ditentukan berdasarkan sifat mekanik bahan terutama pada kekuatan tarik dan perpanjangan bahan. Sifat mekanik ini diperoleh melalui percobaan uji tarik. Sifat mekanik suatu bahan dipengaruhi oleh sifat alami masingmasing komponen dan kemampuan ikatan dalam senyawa penyusunnya.

\section{Uji Pengembunan}

Untuk melakukan uji penggembungan, pertamatama sampel yang telah disiapkan ditimbang dan dicatat massa awalnya. Sampel yang telah ditimbang kemudian ditetesi air sebanyak 5 kali disepanjang permukaan sampel, kemudian didiamkan selama 2 menit untuk penyerapan airnya. Setelah itu, sampel ditiriskan dengan tisu kemudian ditimbang kembali dan dicatat massa akhirnya. Untuk mendapatkan derajat penggembungan, data massa yang telah diperoleh lalu disubstitusikan ke dalam persamaan :

$s=\frac{m 2-m 1}{m 1} \times 100 \%$

\section{Uji Titik Leleh}

Uji ini diperlukan untuk mengetahui temperatur leleh dari sampel plastik biodegradable yang dibuat. Sampel plastik biodegradable ditumbuk dengan menggunakan mortar hingga halus. Sampel plastik biodegradable diambil dengan menggunakan spatula kemudian dimasukkan pada beaker glass sampai sampel leleh. Kemudian, suhu dicatat pada rentang suhu sampel mulai meleleh dan semua sampel habis meleleh.

\section{Uji Biodegradabilitas}

Uji biodegradabilitas dilakukan untuk mengetahui waktu yang dibutuhkan sampel film plastik sampai mengalami degradasi. Uji biodegradabilitas yang dipilih yaitu mengendalikan mikroorganisme tanah sebagai pembantu proses degradasi atau yang disebut dengan teknik soil burial test (Subowo dan Pujiastuti, 2003). Sampel berukuran $4 \times 1 \mathrm{~cm} 2$ ditempatkan dan ditanam 
dalam pot yang telah terisi tanah, sampel dibiarkan terkena udara terbuka tanpa ditutupi kaca. Pengamatan terhadap sampel dilakukan dalam rentang waktu satu hari sekali hingga sampel mengalami degradasi secara sempurna.

\section{Hasil dan Pembahasan}

Dari hasil penelitian yang dilakukan telah didapatkan film plastik biodegradable yaitu pada tahap pertama dilakukan pembuatan gliserin dari minyak jelantah setelah diperoleh gliserin dari minyak jelantah. Setelah itu dilakukan pembuatan tepung onggok singkong, kemudian setelah diperoleh gliserin dari minyak jelantah dan tepung dari onggok singkong dilakukan pembuatan plastik biodegradable dengan mencampurkan onggok singkong dan gliserin dari beberapa komposisi dari lima variabel yang berbeda. Setelah kering pada suhu $60^{\circ} \mathrm{C}$ selama 12 jam plastik dilepaskan dari cetakannya. Hasil film dari kelima variabel ada yang berupa lembaran berwarna sedikit coklat muda, transparan dan elastis yang kemudian diuji ketahanannya terhadap kuat tarik, uji leleh, uji ketahanan terhadap air, serta biodegradabilitasnya untuk mengetahui standar kelayakannya.

\section{Uji Tarik}

Semakin besar komposisi gliserol yang ditambahkan, maka sifat bioplastik akan semakin elastis. Hal ini disebabkan oleh semakin menurunnya jarak ikatan intermolekulernya, sehingga dari segi uji tarik komposisi terbaik yang didapat dari kelima variabel yaitu pada variabel ketiga dengan penambahan gliserin sebanyak $15 \mathrm{ml}$.

\section{Uji Pengembunan}

Uji ini dilakukan untuk mengetahui terjadinya ikatan dalam polimer serta tingkatan atau keteraturan ikatan dalam polimer yang ditentukan melalui prosentase penambahan berat polimer setelah mengalami pengembunan. Proses terdifusinya molekul pelarut kedalam polimer akan menghasilkan gel yang mengembun. Dapat dilihat bahwa onggok singkong 15 gram dan $15 \mathrm{ml}$ gliserin memiliki ketahanan terhadap air paling bagus dibandingkan yang lainnya yaitu dengan presentase $37,5 \%$. Hal ini disebabkan karena tepung onggok singkong memiliki kandungan pati dimana pati sendiri memiliki sifat yang sukar larut dalam air, bahan dasar gliserin dari minyak jelantah juga mempengaruhi karena minyak jelantah tak larut dalam air, jadi semakin besar gliserin dan tepung onggok singkong, maka derajat pengembunan semakin kecil yang berarti bahwa proses penyerapan air paling kecil dibanding variabel lainnya.

\section{Uji Titik Leleh}

Uji Titik Leleh dilakukan untuk mengetahui rentan suhu plastik biodegradable mulai meleleh dan semua sampel habis meleleh. Dalam melakukan uji titik leleh mengalami kendala dalam penggunaan alat uji yaitu melting block sehingga dalam melakukan pengujian titik leleh digunakan alat pemanas yaitu dengan menggunakan hot plate. Dalam uji titik leleh menggunakan hot plate diperoleh hasil rentan suhu yang kurang valid. Karena pada pemanasan sampel tidak dapat meleleh sempurna dan yang dapat diamati hanya pengerutan pada sampel. Dapat dilihat bahwa onggok singkong 15 gram dan $15 \mathrm{ml}$ gliserin mengalami penyusutan dengan suhu paling rendah dibandingkan yang lain. Hal ini disebabkan karena gliserin menyebakan plastik semakin elastis sehingga jika semakin elastis. Kemudian jika dilakukan pemanasan lebih lanjut dengan sifat keelastisannya akan cepat menyusut.

\section{Uji Biodegradable}

Analisis biodegradasi film plastik dilakukan melalui pengamatan film secara visual. dilihat bahwa film plastik yang diuji dalam tanah, mengalami degradasi dalam waktu 9 hari yang ditunjukkan dengan terkoyaknya permukaan film plastik. Hal ini dikarenakan bahwa film plastik yang terbentuk mengandung gugus hidroksil ( $\mathrm{OH}--)$ dan gugus karbonil (CO) dan juga ester $(\mathrm{COOH})$ gugus tersebut menandakan bahwa bioplastik ini mampu terdegradasi dengan baik di dalam tanah. Dari hasil penelitian tersebut, film plastik berbahan tepung onggok singkong dapat dikatakan sebagai plastik yang ramah lingkungan, kondisi sampel pada hari pertama penanaman. Sampel diletakkan diatas galian tanpa penutup kaca dan dibiarkan terkena udara terbuka. Pada hari kedua sampel tidak mengalamai perubahan bentuk, tetapi pada hari ketiga dari kelima variasi gliserin dan onggok singkong tersebut mengalami perubahan yaitu kelima sampel dari plastik biodegradable semakin berkurang. Kelima sampel terdapat lubang di bagian-bagian tertentu, untuk sampel 15 gram onggok singkong dan $15 \mathrm{ml}$ gliserin. Pada hari ke delapan, keseluruhan sampel mengalami degradasi secara sempurna. Kerusakan yang tidak beraturan ini menunjukkan bahwa mikroorganisme tanah juga mempengaruhi pada degradasi sampel plastik berbasis onggok singkong. Sampel plastik tidak ditemukan atau sudah habis pada hari ke-sembilan, yang menunjukkan bahwa keseluruhan sampel berukurang dan telah terdegradasi dibanding sampel yang lainnya.

\section{Kesimpulan}

Berdasarkan hasil penelitian yang diperoleh,komposisi tepung onggok singkong dan gliserin dari minyak jelantah memberikan pengaruh terhadap sifat fisik bioplastik. Sifat fisik bioplastik terbaik terdapat pada komposisi 15 gram tepung onggok singkong dan $15 \mathrm{ml}$ gliserin dengan derajat pengembunan $37,5 \%$, dengan hasil analisis uji kuat tarik, titik leleh paling baik dibanding variabel lainnya. Semakin banyak gliserin yang digunkan maka sifat palstik akan semakin elastis. Plastik biodegradable dari onggok singkong dengan plasticizer gliserin dari minyak jelantah dapat terdegradasi selaa 9 hari, sehingga Plastik biodegradable adalah plastik ramah lingkungan.

\section{Daftar Pustaka}

Arban, A. 2007. Pengaruh Penambahan Pemlastis Polietilen Glikol 400, Dietil Glikol, dan Dimetil Ftalat terhadap Proses Biodegradasi Plastik biodegradable Poli Hidroksialkanoat pada Media 
Cair dengan Udara Terlimitasi. Skripsi. Bogor: Fakultas Teknologi Pertanian IPB

Darni, Y., Utami, H. 2010. Studi Pembuatan dan Karakteristik Sifat Mekanik dan Hidrofobisitas Bioplastik dari Pati Sorgum. Jurnal Rekayasa Kimia dan Lingkungan, 7( 4), 190-195.

Katz, S., 1995. Degradation of Polymers. Materials World, 377-378.

Mursyid, W. M. A., Bachruddin, Z., Zuprizal, Cahyanto, M. N. 2008. Nilai Nutritif Onggok-Terfermentasi
Mutan Trichoderma AA1 Pada Ayam Broiler. Media Kedokteran Hewan, 24, 165-170.

Subowo, S., S. Pujiastuti. 2003. Plastik yang Terdegradasi Secara Alami (Biodegradable) Terbuat darï Ldpe dan Pati Jagung Terlapis. Prosiding Simposium Nasional Polimer IV, 203208.

Spink W.P., Waychoff W.F. 1958. Plasticizers. Modern Plastic Encyclopedia Issue. Hildrent Press Inc, New York. 